\title{
Global Havoc due to COVID-19 and Its Impact on Dentistry: A Review
}

\author{
Deshraj Jain ${ }^{1}$, Alka Gupta ${ }^{2}$, Unnati Gedam ${ }^{3}$, Amit Varma ${ }^{4}$ \\ ${ }^{1}$ Professor \& Head, ${ }^{2}$ Professor, ${ }^{3}$ Postgraduate Student, \\ Dept. of Prosthodontics, Government College of Dentistry, Indore, (M.P.) India \\ ${ }^{4}$ Postgraduate Student, Dept. of Oral and Maxillofacial Surgery, Government College of Dentistry, Indore
}

Corresponding Author: Unnati Gedam

\begin{abstract}
The coronavirus disease 2019 (COVID-19), originated in Wuhan, China. The disease has now affected more than 100 countries around the world. In the light of the WHO declaring COVID-19 as a public health emergency of international concern, despite global efforts to prevent the spreading of the disease, the cases are still increasing. Dentistry is facing its darkest hour, with the growth and spread of this pandemic. Dental surgeons are among the highest risk because they are in direct contact with saliva. COVID-19 had a serious impact on the dental profession. There are lot many articles published relating to Dentistry and the disease. But dentistry has various specialties and each of them has specific therapeutic considerations. The article concisely elaborates specific considerations in various specialties in dentistry.
\end{abstract}

Keywords: COVID-19, Dentistry, Impact on dentistry, Therapeutic considerations, Review

\section{INTRODUCTION}

The outbreak of coronavirus disease 2019 (COVID-19) in Wuhan, China, has evolved rapidly into a public health crisis and has spread drastically to other parts of the world ${ }^{[1,2]}$. The emergence of the highly infectious novel coronavirus, affecting more than 100 countries has led to a global pandemic in a span of just 3 months. It was only on 31 December 2019 that the first reports of pneumonia of an unknown cause detected in Wuhan, China, became known to the World Health Organization (WHO). It was a new strain, which was not detected previously in humans. Consequently, on 30 January 2020, the World Health Organization (WHO) declared the outbreak a Public Health Emergency of International Concern (PHEIC). The virus causing COVID-19 was initially referred to as 2019-nCoV and was later referred to as Coronavirus 2 syndrome (SARS CoV 2) by the International Committee on Virus Taxonomy ${ }^{[3-5]}$.

"The Workers Who Face the Greatest Coronavirus Risk" ${ }^{[6]}$ is an article published in The New York Times, where a remarkable schematic representation showed that dentists were at the highest risk of contact with the virus as they encounter direct exposure to saliva and droplets. Amnesty International (also referred to as Amnesty or AI), London, in September 2020 has reported more than 7000 health care workers have died due to COVID all over the world, 573 in India alone. In order to resolve and monitor its spread, dentists should ideally maintain a high degree of proficiency and honesty. The Centers for Disease Control and Prevention (CDC), the American Dental Association (ADA), and the WHO are providing specific recommendations for dentists to control the spread of COVID-19 ${ }^{[7,8]}$. 
Dentistry is facing its darkest hour, with the growth and spread of this pandemic. Dental surgeons are among the highest risk of contracting and transmitting the SARS-CoV-2, in conjunction with paramedics, nurses, and other healthcare workers. India declared its first complete lockdown from March 25, 2020, 00.00 am. Since then, dental clinics across the country have been shut down for more than 2 months. With the pandemic still on the growth curve and showing little signs of decline, the hope of reviving dentistry anytime soon is bleak ${ }^{[9]}$.

\section{STUDY DESIGN AND METHODS}

The research was done electronically using databases such as PubMed/Medline, Google Scholar, Web of Science, EBSCO, Scopus, focusing on COVID-19 from 20192021 and its epidemiology, route of transmission, risk factors in dental clinics, sterilization protocols, disinfection norms, and importance of self-protection of the dentist. This investigation aimed to find the best possible ways to understand the current scenario and to protect oneself from all the myths.

\section{Epidemiology:}

The first case of COVID-19 in India, a student who had returned to his hometown for a vacation from Wuhan University, was confirmed on January 30 in Kerala's Thrissur district. Globally, as of March 2021, there have been 125,781, 957 confirmed cases of COVID-19, including $2,759,432$ deaths, reported to WHO. As of 24 March 2021, a total of 462,824,374 vaccine doses have been administered ${ }^{[10]}$.

The second wave of increased incidence is reported in many countries. The second wave of COVID-19 is widely feared at the end of 2020 as many jurisdictions around the world begin lifting restrictions that have held viral transmission in check and were likely across a broad range of epidemiological and behavioral parameters [11]. Researchers urged that the current pandemic might last for more than two to three years and could slow down when more than $65 \%$ of the population around the world achieve immunity ${ }^{[12]}$. They also urged that the current wave of a pandemic might be followed by repeated smaller waves which are supposed to appear consistently. Similarly, the expected secondary and tertiary waves in the future could be geographically different, and their intensity might be dependent on the local control measures ${ }^{[13]}$.

\section{Route of Transmission:}

The three most common
transmission routes ${ }^{[14]}$ of novel CoV
include:

1. Direct transmission (through cough, sneeze, or droplet inhalation)

2. Contact transmission (through oro-nasal-ocular route) and

3. Aerosol transmission.

Specific therapeutic considerations in various specialities in dentistry: Oral Diagnosis and Radiology:

Diagnosis of the oral cavity at the patient's first visit should be precisely done as it may provide information on the patient's present or past conditions related to COVID-19. Dysgeusia is the first recognized oral symptom of novel coronavirus disease (COVID-19). Aphthous-like lesions, herpetiform lesions, candidiasis, and oral lesions of Kawasakilike disease are the most common oral manifestations of COVID-19 disease. Older age and severity of COVID-19 disease seem to be the most common factors that predict the severity of oral lesions in these patients. Lack of oral hygiene, opportunistic infections, stress, underlying diseases (diabetes mellitus, immunosuppression), trauma (secondary to intubation), vascular compromise, and hyperinflammatory response secondary to COVID-19 are the most important predisposing factors for the development of oral lesions in COVID-19 patients $^{[15]}$.

Recent reports suggest the appearance of COVID Tongue. According 
to the British Journal of Dermatology, a significant number of COVID -19 patients are experiencing bumps on their tongue, along with inflammation and swelling. Also, various studies are being conducted to evaluate the prevalence of fungal diseases like mucormycosis in COVID-19 patients. A dentist should be vigilant and watch out for these oral manifestations.

For diagnosis purposes, using extraoral radiographs such as panoramic radiographs (OPG) or Cone Beam
Computed Tomography (CBCT) is endorsed over the intraoral radiographs.

\section{Oral and Maxillofacial Surgery:}

$$
\text { Routine Minor surgical }
$$

procedure: Most routinely done minor surgeries like third molars and dental implants, which are the bread and butter of our practice, needs restructuring during this COVID-19 pandemic ${ }^{[16]}$ and are elaborated in Table 1.

Table 1: Recommendation for minor surgical procedures

\begin{tabular}{|c|c|}
\hline Simple extractions & $\begin{array}{l}\text { The patient should preferably be kept in a supine position to increase the distance from his oral cavity and avoid } \\
\text { working within the direct exhalation pathway of the patient. }\end{array}$ \\
\hline Third molars & $\begin{array}{l}\text {-Use chisels and osteotomes. } \\
\text {-Use hand instruments. } \\
\text {-Motors at low speed. } \\
\text {-Piezoelectric Osteotomy. } \\
\text {-Er:YAG lasers. } \\
\text {-Resorbable sutures to be used to avoid repeat appointments }\end{array}$ \\
\hline $\begin{array}{l}\text { Soft Tissue } \\
\text { Procedures }\end{array}$ & $\begin{array}{l}\text {-Prefer scalpel over electrocautery. } \\
\text {-Use hemostats and other hand instruments and local agents for hemostasis. }\end{array}$ \\
\hline Implants & $\begin{array}{l}\text {-Using physiodispensor, speed as low as } 50 \mathrm{rpm} \text { with or without irrigation. } \\
\text {-Use active self-drilling types of implants over passive implants. } \\
\text {-Sinus lift technique using osteotomes for indirect lifts at least wherever possible. } \\
\text {-Direct sinus lifts itself, and bone grafts can be avoided by resorting to pterygoid/zygomatic implants or all of four } \\
\text { techniques. }\end{array}$ \\
\hline
\end{tabular}

Major surgical procedure: In most developed nations, it has been proposed to postpone/scheduled elective procedures during this pandemic to protect the community, patients, and staff, while providing emergency care only ${ }^{[17]}$.

Performing SARS-CoV-2 tests on all patients admitted in oral and maxillofacial surgical wards on a routine basis as suggested by some authors ${ }^{[18]}$ is not practical in our situation. Literature shows that conventional chest radiographs have the potential of giving a clue of the presence of COVID-19 [19]. Therefore, routine investigation such as a chest X-ray which is done in all cases in our setting may be relied upon as a preliminary indicator. The recommendations for major surgical procedures ${ }^{[19]}$ are described in Table 2.

Table 2: Recommendations for The management of surgical procedures in Oral and Maxillofacial Surgery during the COVID-19 pandemic.

\begin{tabular}{|c|c|c|}
\hline Situation & Major surgical procedure & Recommendation \\
\hline \multirow[t]{2}{*}{ Elective surgery in COVID-19 patient } & $\begin{array}{l}\text {-Orthognathic surgeries } \\
\text {-Cleft lip and palate } \\
\text {-Secondary Reconstruction } \\
\text {-TMJ Disorders Causing mild pain } \\
\text {-Craniofacial Malformation }\end{array}$ & Postpone until a pandemic has settled \\
\hline & $\begin{array}{l}\text {-Benign Tumor } \\
\text {-Nondisplaced/minimal Fracture } \\
\text {-Cystic lesion } \\
\text {-Severe TMJ pain }\end{array}$ & Surgery: After COVID 19 Report negative \\
\hline \multirow[t]{2}{*}{ Urgent surgery in COVID-19 patient } & $\begin{array}{l}\text {-Malignant tumors } \\
\text {-Displaced Fracture } \\
\text {-Orbital decompression }\end{array}$ & Surgery; After COVID-19 Report Negative \\
\hline & $\begin{array}{l}\text {-Comminuted fractures } \\
\text {-Tracheotomy }\end{array}$ & Surgery with proper protocol \\
\hline Emergency surgery in COVID-19 patient & $\begin{array}{l}\text {-Space Infection } \\
\text {-Severe hemorrhage }\end{array}$ & Surgery with proper protocol \\
\hline
\end{tabular}

Endodontics and Conservative Dentistry:

Ather et al ${ }^{[20]}$ reviewed symptoms, routes of transmission, and epidemiology of 
the disease and a set of recommendations for the management of guidelines regarding endodontic intervention. It is advisable to assess the emergencies on a case-by-case basis and use clinical judgment to aid in decision-making ${ }^{[21]}$. The treatment protocol in Endodontics as describe by Ather et al. is summarized in Table 3.

Table 3: Treatment protocol in Endodontics

\begin{tabular}{|l|l|l|}
\hline Condition & Immediate protocols & Delayed protocols \\
\hline $\begin{array}{l}\text { Irreversible pulpitis/ Acute apical } \\
\text { periodontitis (if symptomatic) }\end{array}$ & $\begin{array}{l}\text {-Pain management with appropriate NSAIDs / } \\
\text { Nonopioid } \\
\text {-Long-acting local anesthetic } 0.5 \% \\
\text { Bupivacaine for immediate pain relief) }\end{array}$ & Full pulpotomy with proper protocol \\
\hline Acute Apical Abscess & $\begin{array}{l}\text {-Incision and Drainage with proper protocol } \\
\text {-Proper Antibiotics }\end{array}$ & Refer to Oral \& Maxillofacial Surgery \\
\hline Avulsion/ Luxation & $\begin{array}{l}\text { If a tooth is replanted, follow pain } \\
\text { management protocol }\end{array}$ & $\begin{array}{l}\text { If a tooth is not replanted, replant and follow } \\
\text { IADT } \\
\text { (International Association of Dental } \\
\text { Traumatology) guidelines. }\end{array}$ \\
\hline Tooth fracture resulting in pain & Pain management & Vital Pulp Therapy with proper protocol \\
\hline
\end{tabular}

In view of the recommendations of the Brazilian Federal Council of Dentistry, during the COVID-19 pandemic, only emergency and urgent care are recommended ${ }^{[22]}$. The restorative procedures that are considered dental emergencies are dental trauma, extensive caries, or defective restorations that cause pain and fabrication of provisional restorations if the restoration is lost, broken, or is causing gingival irritation ${ }^{[23]}$. The recommendation for dental restorative procedures is summarized in Table 4.

Table 4: Recommendations regarding dental restorative procedures

\begin{tabular}{|c|c|c|}
\hline Material & Recommendations & Advantages \\
\hline $\begin{array}{l}\text { Dental } \\
\text { handpieces }\end{array}$ & Anti-retraction dental handpiece & $\begin{array}{l}\text {-Avoid cross-contamination, } \\
\text {-Reduce the production of aerosols }\end{array}$ \\
\hline Water spray & $\begin{array}{l}\text {-High-speed handipiece without abundant water spray is the } \\
\text { most recommended. } \\
\text {-It-not recommended using the triple syringe }\end{array}$ & Avoid high production of aerosols \\
\hline $\begin{array}{l}\text { Rubber dam } \\
\text { isolation }\end{array}$ & $\begin{array}{l}\text { Rubber dam isolation of the operative field during cavity } \\
\text { preparation should be used. }\end{array}$ & $\begin{array}{l}\text { Minimizes the production of contaminated } \\
\text { aerosol. }\end{array}$ \\
\hline Suction pumps & $\begin{array}{l}\text { High-powered suction systems are necessary during a } \\
\text { restorative procedure }\end{array}$ & $\begin{array}{l}\text { To eliminate infectious droplets as soon as they } \\
\text { are emitted, and thereby minimizing their } \\
\text { dispersion in the air. }\end{array}$ \\
\hline $\begin{array}{l}\text { Cavity } \\
\text { preparation }\end{array}$ & $\begin{array}{l}\text {-Manual removal of carious tissue by using dentine excavators } \\
\text {-Use of chemical caries removal techniques }\end{array}$ & Avoid high production of aerosols \\
\hline $\begin{array}{l}\text { Adhesive dental } \\
\text { materials }\end{array}$ & $\begin{array}{l}\text {-Universal adhesive systems are products easy to use since the } \\
\text { same product has several technical possibilities } \\
\text {-Bulk-Fill composite resins }\end{array}$ & $\begin{array}{l}\text { A minimum time permanence in the dental office } \\
\text { and minimize the chances of cross-infection. }\end{array}$ \\
\hline
\end{tabular}

\section{Orthodontics:}

According to García-Camba $P$ (2020) ${ }^{[24]}$, some of the adaptations needed will improve the orthodontist's line of work when the pandemic will be defeated, but others will not be sufficiently costeffective.

Table 5: Various orthodontic emergencies and their solutions for the patients

\begin{tabular}{|c|c|c|}
\hline Appliance & Classification & Orthodontic protocols \\
\hline \multirow{3}{*}{$\begin{array}{l}\text { Removable } \\
\text { appliances }\end{array}$} & Functional & If it is broken or does not fit - suspend its use. \\
\hline & Aligner & If broken or lost, get back to the previous set and contact the orthodontist. \\
\hline & Retainers & $\begin{array}{l}\text { If broken or lost, consult the Orthodontist with proper photographs of the } \\
\text { broken appliance. }\end{array}$ \\
\hline \multirow[t]{3}{*}{$\begin{array}{l}\text { Fixed } \\
\text { appliances }\end{array}$} & $\begin{array}{l}\text { Non-removable appliances - Pre adjusted } \\
\text { appliance }\end{array}$ & $\begin{array}{l}\text { Loose bracket:-Eventually, remove with a Tweezer. } \\
\text { Poking distal wire/ ligature wire:-Use ortho wax or cut with a disinfected } \\
\text { nail cutter or hardware cutter. } \\
\text { An abscess around a band:-Prescribe topical NSAID sprays or ointment, } \\
\text { antibiotics and hot saline rinses. }\end{array}$ \\
\hline & $\begin{array}{l}\text { Non-removable appliances activated by patients } \\
\text { (face masks, headgears, palatal expanders) }\end{array}$ & Must be suspended to prevent any emergency. \\
\hline & $\begin{array}{l}\text { Preactivated non-removable appliances } \\
\text { (pendulum, forsus, distal jet, Transpalatal bar) }\end{array}$ & $\begin{array}{l}\text { If the patient complains of any swelling or pain, contact the orthodontist. } \\
\text { It should be treated as an emergency and removed from the oral cavity. }\end{array}$ \\
\hline
\end{tabular}


Braces treatment is a time-taking treatment, which ranges from 1 to 2 years; One can settle on a decision to postpone orthodontic appointments ${ }^{[25]}$. An orthodontic emergency might be described as a problem arising from an orthodontic appliance, where an unscheduled appointment is required to resolve the issue. Patients who present with an orthodontic emergency may be experiencing pain or discomfort ${ }^{[26]}$. The orthodontic emergencies with their solutions are summarized in Table $5^{[25,26]}$.

\section{Periodontics:}

Periodontal treatment can be considered as dangerous work compared to other dental procedures regarding the aspect of bioaerosol generation ${ }^{[27]}$. The following are evidence-based guidelines drawn up based on past and current experimental and clinical studies for the recommencement of periodontal practice ${ }^{[28]}$. The recommendations for periodontal treatments are summarized in Table 6 and periodontal emergencies ${ }^{[29]}$ are described in Table 7.

Table 7: List of the Periodontal emergency treatments ${ }^{[32]}$

\begin{tabular}{|l|l|l|}
\hline $\begin{array}{l}\text { Periodontal } \\
\text { procedures }\end{array}$ & Surgical & Medications \\
\hline $\begin{array}{l}\text { Acute periodontal } \\
\text { abscess }\end{array}$ & $\begin{array}{l}\text {-Subgingival scaling / curettage with hand } \\
\text { instruments with Proper Protocol. }\end{array}$ & $\begin{array}{l}\text { - Nonopioid pain medication (acetaminophen 500 mg) + NSAID } \\
- \text { Incision and drainage (if necessary) with } 600 \mathrm{mg} \text { ) if necessary. }\end{array}$ \\
$\begin{array}{l}\text { Proper Protocol. } \\
\text {-Aminopenicilline (amoxicillin / clavulanic acid 875/125 mg) or } \\
\text { lincosamide (clindamycin } 600 \mathrm{mg} \times 5 \text { days) if necessary. }\end{array}$ \\
\hline
\end{tabular}

Additional research in Periodontology: A hypothesis put forward by Jagannathan et $a l^{[30]}$, whether patients with periodontal disease are at increased risk of SARS-CoV2 infection due to elevated levels of Furin and Cathepsin in the oral cavity and COVID-19 complications like cytokine storm could occur with increased frequency in patients with periodontal disease due to the significant increase of CD14+ CD16+ monocytes in the blood. Oral and periodontal examination of patients with mild, moderate, and severe SARS-CoV-2 infection could shed light on the significant role played by periodontal disease in making an individual more prone to get SARS-CoV-2 infection by elevation of Furin and Cathepsin and the elevation of
CD14+CD16+ monocytes and proinflammatory cytokines in the blood that could consequently worsen COVID-19 complications like cytokine storm. The blood counts of CD14+CD16+ monocytes need to be assayed in SARS-CoV-2 patients with and without the periodontal disease to observe if periodontal disease as a coexisting condition elevates the proportion of CD14+CD16+ monocytes in SARSCoV-2 patients. Assessment of monocyte subsets in peripheral blood could be used as an immunosurveillance marker in SARSCoV-2 patients. Hence, SARS-CoV-2 positive patients with chronic periodontal disease should be closely monitored for potential signs of a cytokine storm and its related complications ${ }^{[31-33]}$.

\section{Oral Pathology:}

Table 8: Practical guidelines to minimize risk in Oral pathology

\begin{tabular}{|l|l|l|}
\hline \multicolumn{2}{|l|}{ Procedure } & Recommendations \\
\hline Examination & & $\begin{array}{l}\text {-Until and unless there is an emergency. } \\
\text {-The use of antimicrobial mouth rinse. }\end{array}$ \\
\hline $\begin{array}{l}\text { Histopathology } \\
\text { practice }\end{array}$ & Specimen receiving & $\begin{array}{l}\text {-All specimens should be labeled properly with patient details and status of } \\
\text { COVID-19 (negative, suspected, positive , or Not Tested). } \\
\text {-COVID suspect or positive patients, communication to oral pathology laboratory } \\
\text { is recommended. }\end{array}$ \\
\cline { 2 - 3 } & $\begin{array}{l}\text { Grossing of specimens } \\
\text {-One area of grossing should be decided for COVID-19 suspected/positive } \\
\text { samples, where air conditioning systems should be switched off with provision for } \\
\text { cross ventilation facility and exhaust system. } \\
\text {-Any aerosol-generating procedure such as bone cutting should be avoided. Hand } \\
\text { saw should be preferred over electric bone saw in those conditions }\end{array}$ \\
\cline { 2 - 3 } & $\begin{array}{l}\text { Storage and discarding of } \\
\text { specimens }\end{array}$ & $\begin{array}{l}\text { All specimens marked as COVID-19 suspected or positive should be separately } \\
\text { stored in a different shelf, clearly labeled as COVID-19 specimens. }\end{array}$ \\
\hline
\end{tabular}




\begin{tabular}{|c|c|c|}
\hline & \multicolumn{2}{|r|}{ Table 8: Continued... } \\
\hline & $\begin{array}{l}\text { Histological processing of } \\
\text { specimens }\end{array}$ & $\begin{array}{l}\text { Corona-virus are found to be inactivated at } 56^{\circ} \mathrm{C} \text { for } 90 \mathrm{~min}, 67^{\circ} \mathrm{C} \text { for } 60 \text {, and } \\
75^{\circ} \mathrm{C} 9 \text { for } 30 \mathrm{~min} \text {. }\end{array}$ \\
\hline & $\begin{array}{l}\text { Frozen sections and direct } \\
\text { immunofluorescence }\end{array}$ & $\begin{array}{l}\text {-As the frozen section involves the use of unfixed specimens and is considered an } \\
\text { aerosol-generating procedure, it should be deferred during this period of COVID- } \\
19 \text { pandemic. }\end{array}$ \\
\hline \multirow[t]{3}{*}{$\begin{array}{l}\text { Cytological } \\
\text { Practice }\end{array}$} & & $\begin{array}{l}\text { It can be avoided or should be limited to emergency procedures with the use of } \\
\text { proper precautions. }\end{array}$ \\
\hline & $\begin{array}{l}\text { Performing } \\
\text { procedures }\end{array}$ & $\begin{array}{l}\text {-Follow proper protocol } \\
\text { If FNAC is to be done from lymph node/extraoral swelling, the patient should } \\
\text { wear a mask throughout the procedure. However, while sampling from the oral } \\
\text { cavity, the patient's head positioning should be in a way to avoid his/her direct } \\
\text { breathing toward pathologists. }\end{array}$ \\
\hline & Processing of specimens & $\begin{array}{l}\text {-Fresh, unfixed specimens should be transported by hand and not shipped with } \\
\text { pneumatic-tube systems. } \\
\text {-Preparation of air-dried smears should be avoided. }\end{array}$ \\
\hline $\begin{array}{l}\text { Hematological } \\
\text { Investigations }\end{array}$ & & $\begin{array}{l}\text {-Health-care workers collecting the sample (blood, serum, and plasma) should } \\
\text { follow universal precautions. } \\
\text { - Sealed centrifugation should be preferred. }\end{array}$ \\
\hline
\end{tabular}

Personal hygiene, social distancing, and precautions during all steps in the oral pathology such as sampling, sample receiving, sample processing, and reporting, etc., will ensure the safety of all laboratory personnel during this epidemic. An overview of the practical guidelines to minimize risk in Oral pathology by Mishra $D^{[34]}$ is summarized in Table 8.

\section{Pediatric Dentistry:}

The pediatric dental practice aims to maintain the well-being and safety of children during this Pandemic. Hence a risk assessment of the practice should be carried out to identify the measures required to minimize the risk of COVID-19 transmission.

Toys, magazines, and other frequently touched objects in the waiting area which cannot be cleaned or disinfected regularly are removed from the waiting area. Triage by telemedicine (telephones, video-call applications on cell phones, video monitoring, or tablets) and manages patients suspected of COVID-19 without a face-toface visit. If the signs and symptoms are present then the appointment is rescheduled [35].

Minimally invasive/atraumatic restorative techniques (hand instruments) should be prioritized, aerosol-generating procedures via dental handpiece and air/water syringe should be avoided and ultrasonic scalers discontinued. When aerosol-generating procedures are necessary use four-handed dentistry to droplet spatter and aerosols may be minimized via a high evacuation suction and dental dam.

\section{Prosthodontics, Crown \& Bridge and Implantology:}

Prosthodontics, which is a specialty of dentistry which deals with services to the Geriatric age group in form of Complete Denture, Removable Denture, Implantsupported Prosthesis, and Crown and Bridge to replace missing teeth in any adult age group. The challenge to a Prosthodontist is going to be much more because of factors such as high concentration of copious saliva in trays \& dentures, exposure to blood during pre-prosthetic surgeries, and implant placement and exposure to aerosols during tooth preparation for crown and bridge ${ }^{[36]}$.

Prosthodontic treatment does not fall in emergency treatments ${ }^{[37]}$. According to Australian Dental Association guidelines, dental trauma due to denture fracture, repair of broken dentures, need for temporary or immediate dentures, final crown or bridge repair or rehabilitation of interim crowns, the problem with implants or implant prosthesis, and ulceration due to sharp edges of tooth or prosthesis require urgent treatment so that the patient can carry his/her daily chores without any difficulty [38-40]

Only urgent treatment should be carried out if the patient shows clinical symptoms. Patients who are COVID-19 positive should be only treated if they have 
ulcerations due to sharp edges of tooth or prosthesis, any temporomandibular dysfunction management, and denture problems. No elective implants should be done. No patient should be entertained in the dental clinic till the time he/she is agitated with his/her final crown or bridge repair or cementation is lost or broken ${ }^{[40]}$. The guidelines for infection control in prosthodontics ${ }^{[36,40]}$ is summarized in Table 9.

Table 9: Guidelines on Infection control in Prosthodontics department

\begin{tabular}{|c|c|c|}
\hline \multicolumn{2}{|l|}{ Materials } & \multirow{2}{*}{$\begin{array}{l}\text { Recommendations } \\
\text { - Soaking of a denture in } 3 \% \text { Hydrogen Peroxide for } 30 \mathrm{mins} \text {. } \\
\text { - Soaking in } 0.2 \% \text { Chlorhexidine gluconate for } 10 \mathrm{mins} \text { (More } \\
\text { potent than Sodium hypochlorite). } \\
-100 \% \text { Vinegar (acetic acid) for } 6-8 \text { hours. }\end{array}$} \\
\hline $\begin{array}{lr}\text { Complete } & \text { Dentures / } \\
\text { Removable } & \text { partial } \\
\text { denture } & \end{array}$ & & \\
\hline \multirow[t]{2}{*}{ Impressions } & $\begin{array}{l}\text { Alginate/ Zink oxide eugenol } \\
\text { impression paste }\end{array}$ & $-0.5 \%$ Sodium Hypochlorite or iodophors or $2 \%$ Gluteradehyde. \\
\hline & $\begin{array}{l}\text { Elastomeric impression materials } \\
\text { (poly vinyl silicones) }\end{array}$ & $-2 \%$ Gluteraldehyde or Cidex. \\
\hline \multirow[t]{3}{*}{ Trays \& Cast } & & $\begin{array}{l}\text {-Prefer disposable tray. } \\
\text {-Metal tray to be autoclaved. }\end{array}$ \\
\hline & Plastic / bite rim & $2 \%$ Gluteraldehyde solution for 10 mins. \\
\hline & Dental casts and die & Immersed in Sodium Hypochlorite for $10 \mathrm{~min}$. \\
\hline \multirow[t]{8}{*}{ Other equipments } & Articulator & Wipe with $70 \%$ ethyl alcohol. \\
\hline & $\begin{array}{l}\text { Burs - steel } \\
\text { Tungsten - carbide }\end{array}$ & $\begin{array}{l}\text { Washed with metallic brush and soap, cleaned, dried, and } \\
\text { immense in } 2 \% \text { glutaraldehyde, washed out. }\end{array}$ \\
\hline & Face bows & Wipe, spray, or immersion with appropriate disinfectant solution. \\
\hline & Handpieces & Wipe, spray, or immersion with appropriate disinfectant solution. \\
\hline & Air motor for slow-speed handpieces & $\begin{array}{l}\text { Scrubbed with soap and water, lubricate, encompassing the } \\
\text { handpiece by a gauze pad immersed within } 2 \% \text { glutaraldehyde for } \\
10 \text { min, wash with water. }\end{array}$ \\
\hline & Polishing stones & Wash with soap and water; autoclave. \\
\hline & Tooth shade & Wipe, spray, or immersion with appropriate disinfectant solution \\
\hline & Wax bite block, wafer & Wash, submerge in $0.1 \%$ sodium hypochlorite for $10 \mathrm{~min}$, wash out \\
\hline
\end{tabular}

\section{Second wave of COVID-19:}

The second wave of new severe acute respiratory syndrome coronavirus 2 (Covid-19) cases is terrifying. In fact resurgence of cases has been reported in several countries that had seen flattening of the epidemic curve. In general, the relaxation of community control measures is almost always blamed for the resurgence of cases. A medical hypothesis titled, 'The second wave of Covid-19 is determined by immune mechanism' describes an immunological explanation for the doublepeaked epidemic curve of new viral diseases including Covid-19. According to this hypothesis, the second wave of cases is due to the effective innate immunity in some of the population. These individuals may later develop clinical disease upon repeated exposure. This theory claims that a doublepeaked pattern of new cases in a new viral epidemic is intrinsically determined by the pattern of pathogen interaction with the host. According to this hypothesis, relaxation of the community control measures is not responsible; at least in part, for the resurgence of cases ${ }^{[41]}$.

Another article states the second wave of COVID-19 is widely feared as many jurisdictions around the world begin lifting restrictions that have held viral transmission in check. To address this issue, they analyzed a simple theoretical model of the interplay between SARS-CoV-2 transmission dynamics and social dynamics concerning public support for physical distancing and school and workplace closure. They concluded that the second wave of COVID-19 (and sometimes also a third wave) was likely across a broad range of epidemiological and behavioral parameters $^{[7]}$.

\section{CONCLUSION}

The role of a dentist in COVID 19 is beyond dentistry. COVID 19 has had a crippling impact on dentistry. It is commendable that dentists in several countries have been actively participating in this pandemic. Dental procedures can be a 
potential source of transmission of the disease. So, it is the responsibility of a dentist to take adequate and best possible measures to prevent the spread. In these times of hardship, it is an urge for all the dental specialists across the world to get involved, as good times are ahead. Nothing lasts forever, as this too shall pass.

\section{Acknowledgement: None}

\section{Conflict of Interest: None}

\section{Source of Funding: None}

\section{REFERENCES}

1. Centers for Disease Control and Prevention. Transmission of Coronavirus Disease 2019 (COVID-19). Available from: https://www. cdc.gov/coronavirus/2019ncov/about/transm ission.html. [Last accessed on 2020 Aug 15].

2. Dong E, Du H, Gardner L. An interactive web-based dashboard to track COVID-19 in real time. Lancet Infect Dis 2020;20:533-4.

3. Huang C, Wang Y, Li X, Ren L, Zhao J, Hu $\mathrm{Y}$, et al. Clinical features of patients infected with 2019 novel coronavirus in Wuhan, China. Lancet. (2020) 395:497506. doi: 10.1016/S0140-6736(20) 30183-5

4. Li Q, Guan X, Wu P, Wang X, Zhou L, Tong $\mathrm{Y}$, et al. Early transmission dynamics in wuhan, china, of novel coronavirusinfected pneumonia. N Engl J Med. (2020) 382:1199-207. doi: 10.1056/NEJMoa2001316

5. Chen N, Zhou M, Dong X, Qu J, Gong F, Han Y, et al. Epidemiological and clinical characteristics of 99 cases of 2019 novel coronavirus pneumonia in Wuhan, China: a descriptive study. Lancet. (2020) 395:50713. doi: 10.1016/S0140-6736(20)30211-7.

6. Gamio, L. The Workers Who Face the Greatest Coronavirus Risk. Available online:

https://www.nytimes.com/interactive/2020/0 3/15/business/economy/coronavirus-workerrisk.html.

7. Khader $\mathrm{Y}, \mathrm{Al}$ Nsour M, Al-Batayneh OB, Saadeh R, Bashier $\mathrm{H}$, Alfaqih $\mathrm{M}$, et al. Dentists' awareness, perception, and attitude regarding COVID-19 and infection control: Cross-sectional study among Jordanian dentists. JMIR Public Health Surveill 2020;6:e18798.

8. Modi PD, Nair G, Uppe A, Modi J, Tuppekar B, Gharpure AS, et al. COVID-19 awareness among healthcare students and professionals in Mumbai metropolitan region: A questionnaire-based survey. 2020;12: e7514. Published 2020 Apr 2. doi:10.7759/cureus.7514

9. Naviwala GA. COVID-19 and its impact on dentistry. Dent Med Res 2020;8:35-6.

10. https://covid19.who.int/ WHO Coronavirus Disease (COVID-19)

11. Pedro SA, Ndjomatchoua FT, Jentsch $P$, Tcheunche JM, Anand M, Bauch CT. Conditions for a second wave of COVID-19 due to interactions between disease dynamics and social processes. medRxiv. 2020 Jan 1.

12. Kissler SM, Tedijanto C, Goldstein E, Grad $\mathrm{YH}$, Lipsitch M. Projecting the transmission dynamics of SARS-CoV-2 through the postpandemic period. Science. 2020; 368: 860-868.

PubMed: https://pubmed.ncbi.nlm.nih.gov/32291278/

13. Din M, Asghar M, Ali M. COVID19, and dengue coepidemics: A double trouble for overburdened health systems in developing countries. J Med Virol. 2020. PubMed: https://www.ncbi.nlm.nih.gov/pmc/articles/ PMC7404527/

14. Lu CW, Liu XF, Jia ZF. 2019-nCoV transmission through the ocular surface must not be ignored. Lancet 2020;395:e39.

15. Iranmanesh B, Khalili M, Amiri R, Zartab $\mathrm{H}$, Aflatoonian M. Oral manifestations of COVID-19 disease: A review article. Dermatologic therapy. 2021 Jan;34(1):e14578.

16. Chugh A, Kaur A, Kohli A, Kumar P. Oral, and Maxillofacial Minor Surgery Practice Post-COVID 2019 Pandemic - An Insight. Ann Maxillofac Surg. 2020 JulDec;10(2):439-443. doi: 10.4103/ams.ams_189_20. Epub 2020 Dec 23. PMID: 33708592; PMCID: PMC7943980.

17. Edwards SP, Kasten S, Nelson C, Elner V, McKean E. Maxillofacial Trauma Management During COVID-19: Multidisciplinary Recommendations. Facial Plast Surg Aesthet Med. 2020 May/Jun;22(3):157-159. doi: 10.1089/fpsam.2020.0158. Epub 2020 Apr 7. PMID: 32255713. 
18. Zimmermann M, Nkenke E. Approaches to the management of patients in oral and maxillofacial surgery during COVID-19 pandemic. J Craniomaxillofac Surg. 2020 May;48(5):521-526. doi: 10.1016/j.jcms.2020.03.011. Epub 2020 Apr 4. PMID: 32303420; PMCID: PMC7128256.

19. Jacobi A, Chung M, Bernheim A, Eber C. Portable chest X-ray in coronavirus disease19 (COVID-19): A pictorial review. Clin Imaging. 2020 Aug;64:35-42. doi: 10.1016/j.clinimag.2020.04.001. Epub 2020 Apr 8. PMID: 32302927; PMCID: PMC7141645.

20. Ather A, Patel B, Ruparel NB, Diogenes A, Hargreaves KM. Coronavirus Disease 19 (COVID-19): Implications for Clinical Dental Care. J Endod. 2020 May;46(5):584595. doi: 10.1016/j.joen.2020.03.008. Epub 2020 Apr 6. PMID: 32273156; PMCID: PMC7270628.

21. Azim AA, Shabbir J, Khurshid Z, Zafar MS, Ghabbani HM, Dummer PM. Clinical endodontic management during the COVID-19 pandemic: a literature review and clinical recommendations. International endodontic journal. 2020 Nov;53(11):146171.

22. Associação de Medicina Intensiva Brasileira. Conselho Federal de Odontologgia. Recomendações A, para atendimento odontológico COVID C. Comitê de Odontologia AMIB/CFO de enfrentamento ao COVID-19 Departamento de Odontologia AMIB-1 Atualização 25/03/2020. São Paulo: AMIB; 2020.

23. GOMES RD, PEDROSA MD, SILVA CH. Restorative dental treatment in times of COVID-19. RGO-Revista Gaúcha de Odontologia. 2020;68.

24. García-Camba P, Marcianes M, Morales MV. Changes in orthodontics during the COVID-19 pandemic that have come to stay. American Journal of Orthodontics and Dentofacial Orthopedics. 2020 Oct 1;158(4):e1-3.

25. Chakraborty P, Mathur P, Tandon R, Chandra P, Dhingra R. New normality among orthodontists amid pandemic COVID-19. International Journal of Orthodontic Rehabilitation. 2020 Oct 1;11(4):189.

26. Caprioglio A, Pizzetti GB, Zecca PA, Fastuca R, Maino G, Nanda R. Management of orthodontic emergencies during 2019NCOV.

27. Grenier D. Quantitative analysis of bacterial aerosols in two different dental clinic environments. Applied and environmental microbiology. 1995 Aug 1;61(8):3165-8.

28. Khursheed DA. Managing periodontics patients during the SARS-CoV-2 pandemic. Journal of International Oral Health. 2020 Nov 1;12(8):85.

29. Diegritz C, Manhart J, Bücher K, Grabein B, Schuierer G, Kühnisch J, Kunzelmann KH, Hickel R, Fotiadou C. A detailed report on the measures taken in the Department of Conservative Dentistry and Periodontology in Munich at the beginning of the COVID19 outbreak. Clinical oral investigations. 2020 Aug;24(8):2931-41.

30. Jagannathan R, Balaji TM, Rajendran S, Prabhu VR, Varadarajan S, Ajitkumar S. Chronic Periodontal Disease and COVID19 Complications: Mechanistic Links Through Increase of CD14+ CD16+ Monocytes Blood Count. Dental Hypotheses. 2021 Jan 1;12(1):39.

31. Isola G, Polizzi A, Iorio-Siciliano V, Alibrandi A, Ramaglia L, Leonardi R. Effectiveness of a nutraceutical agent in the non-surgical periodontal therapy: A randomized, controlled clinical trial. Clinical Oral Investigations. 2021 Mar;25(3):1035-45.

32. Patini R, Mangino G, Martellacci L, Quaranta G, Masucci L, Gallenzi P. The effect of different antibiotic regimens on bacterial resistance: A systematic review. Antibiotics. 2020 Jan;9(1):22.

33. Jagannathan R, Lavu V, Rao SR. Comparison of the proportion of non-classic (CD14+ CD16+) monocytes/macrophages in peripheral blood and gingiva of healthy individuals and patients with chronic periodontitis. Journal of periodontology. 2014 Jun;85(6):852-8.

34. Mishra D, Kaur H, Kakkar A. Proposal for safe oral pathology laboratory practices in COVID-19 pandemic. Journal of Oral and Maxillofacial Pathology: JOMFP. 2020 May;24(2):217.

35. Shah S. COVID-19 and paediatric dentistrytraversing the challenges. A narrative review. Annals of Medicine and Surgery. 2020 Aug 21.

36. Sekhsaria S, Sharma A, Tiwari B, Sharma A, Mahajan T. Changing paradigm in 
prosthodontics practice post COVID-19 outbreak. IP Ann Prosthodont Restor Dent. 2020;6:1-6.

37. Spagnuolo G, De Vito D, Rengo S, Tatullo M. COVID-19 outbreak: an overview on dentistry. International Journal of Environmental Research and Public Health. 2020 Jan;17(6):2094.

38. Communicable Diseases Network Australia. Guidelines for the public health management of gastroenteritis outbreaks due to norovirus or suspected viral agents in Australia.

39. Alharbi A, Alharbi S, Alqaidi S. Guidelines for dental care provision during the COVID-
19 pandemic. The Saudi dental journal. 2020 May 1;32(4):181-6.

40. Gupta N, Dhawan P, Nautiyal M. Practicing prosthetic dentistry in the COVID era. International Journal of Oral Health Sciences. 2020 Jul 1;10(2):79.

41. Hussein O. Second wave of Covid-19 is determined by immune mechanism. Medical Hypotheses. 2020 Nov 1;144:110238.

How to cite this article: Jain D, Gupta A, Gedam U et.al. Global havoc due to COVID-19 and its impact on dentistry: a review. Int J Health Sci Res. 2021; 11(5): 178-187. DOI: https://doi.org/ 10.52403/ijhsr.20210528

$* * * * * *$ 